\title{
Pengaruh Pendapatan Asli Daerah dan Belanja Modal Pada Kinerja Keuangan Pemerintah Daerah
}

\author{
Cok Istri Nilam Kencana Ningrat ${ }^{1}$ \\ Fakultas Ekonomi dan Bisnis \\ Universitas Udayana, Indonesia. \\ Email: cokistrinilam@gmail.com
}

\author{
Ni Luh Supadmi ${ }^{2}$ \\ Fakultas Ekonomi dan Bisnis \\ Universitas Udayana, Indonesia.
}

\begin{abstract}
ABSTRAK
Penelitian ini bertujuan untuk mengetahui pengaruh Pendapatan Asli Daerah dan Belanja Modal pada Kinerja Keuangan Pemerintah Daerah. Penelitian ini dilakukan pada 38 Organisasi Perangkat Daerah (OPD) yang terdapat di Kabupaten Gianyar. Penelitian ini menggunakan data sekunder, yaitu laporan realisasi APBD tahun 2015-2017. Pengambilan sampel menggunakan teknik sampel jenuh. OPD yang terpilih menjadi sampel sebanyak 36 OPD. Teknik analisis data yang digunakan pada penelitian ini adalah analisis regresi linear berganda. Berdasarkan hasil analisis data menunjukkan bahwa variabel Pendapatan Asli Daerah berpengaruh positif dan signifikan terhadap kinerja keuangan pemerintah daerah, sedangkan variabel Belanja modal berpengaruh negatif dan signifikan terhadap kinerja keuangan pemerintah daerah.
\end{abstract}

Kata Kunci : Pendapatan Asli Daerah; Belanja Modal; Kinerja Keuangan.

The Effect of Regional Revenue and Capital Expenditures on the Financial Performance of Regional Governments

\section{ABSTRACT}

This study aims to determine the effect of Regional Original Income and Capital Expenditures on Local Government Financial Performance. This research was conducted in 38 Regional Organizations (OPD) found in Gianyar Regency. This study uses secondary data, namely the report on the realization of the APBD in 2015-2017. Sampling uses a saturated sample technique. OPD selected as a sample of 36 OPDs. The data analysis technique used in this study is multiple linear regression analysis. Based on the results of data analysis shows that the Regional Original Income variable has a positive and significant effect on the financial performance of local governments, while the capital expenditure variable has a negative and significant effect on the financial performance of local governments.

Keywords: Regional Original Income; Capital Expenditure; Financial Performance.

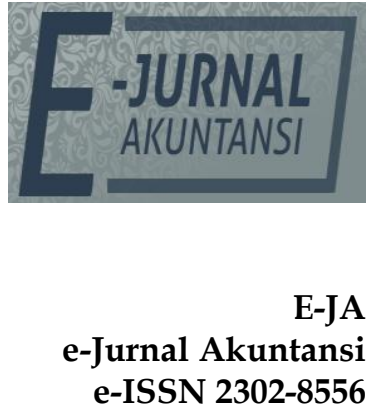

Vol. 29 No. 2

Denpasar, November

2019

Hal. 683-697

Artikel masuk:

06 Juni 2019

Tanggal diterima:

07 Juli 2019 


\section{PENDAHULUAN}

Reformasi yang bergulir tahun 1998 telah membuat perubahan politik dan administrasi, salah satu bentuk reformasi tersebut adalah perubahan bentuk pemerintahan dari sentralisasi menjadi struktur yang terdesentralisasi dengan diberlakunya Undang-undang No. 32 tahun 2004 tentang otonomi daerah kemudian diperbaharui dengan dikeluarkannya UU No. 23 Tahun 2014 tentang pemerintahan daerah. Perangkat Daerah adalah unsur pembantu kepala daerah dan Dewan Perwakilan Rakyat Daerah (DPRD) dalam penyelenggaraan urusan pemerintahan yang menjadi kewenangan daerah. Otonomi daerah merupakan suatu kebebasan yang dimiliki daerah untuk membuat peraturan daerah, menyusun dan melaksakan kebijakan, serta mengelola keuangan daerahnya secara mandiri (Sujarweni, 2015:231). Rosemary et al. (2016) mengungkapkan bahwa alasan diterapkannya kebijakan otonomi daerah karena pemerintah pusat tidak mampu sendiri mengawasi pembangunan daerah secara keseluruhan, oleh sebab itu pemerintah pusat melimpahkan kewenangan terhadap pemerintah daerah untuk mengatur dan mengurus secara mandiri kepentingan-kepentingan daerahnya.

Kemampuan mengelola keuangan yang dilakukan oleh pemerintah daerah tercermin pada Anggaran Pendapatan dan Belanja Daerah seperti kemampuan dari pemerintah daerah dalam meningkatkan penerimaan pendapatan daerahnya serta mampu membiayai pembangunan daerah dan pelayanan publik Rondonuwu et al. (2015). Kabupaten Gianyar merupakan kabupaten dengan pendapatan asli daerah ketiga terbesar dari sembilan kabupaten/ kota di Provinsi Bali. Pendapatan Daerah Kabupaten Gianyar pada tahun anggaran 2015-2017 disajikan pada Tabel 1 berikut.

Tabel 1. Pendapatan Asli Daerah Kabupaten Gianyar Tahun 2015-2017

\begin{tabular}{lccc}
\hline Kabupaten/Kota & \multicolumn{3}{c}{ PAD Kabupaten/Kota (Ribu rupiah) } \\
\cline { 2 - 4 } Tahun & 2015 & 2016 & 2017 \\
\hline & & & \\
Kab. Gianyar & $408.876 .056 .251,25$ & $506.528 .879 .661,32$ & $666.838 .833 .622,64$
\end{tabular}

Sumber: Badan Pengelolaan Keuangan dan Aset Daerah Gianyar, 2019

Berdasarkan Tabel 1 menunjukkan bahwa pendapatan asli daerah Kabupaten Gianyar mengalami peningkatan setiap tahunnya dari tahun 20152017. Peningkatan pendapatan asli daerah ini sesuai dengan filosofi otonomi daerah yaitu mewujudkan kemandirian daerah dari segala segi kehidupan. Tingginya pendapatan asli daerah Kabupaten Gianyar bisa disebabkan oleh beberapa faktor, antara lain kemampuan daerah memanfaatkan potensi yang ada di daerah. Kabupaten Gianyar memiliki potensi sumber daya melimpah yang dapat digali menjadi sumber pendapatan asli daerah dari berbagai bidang atau sektor, seperti pada sektor pariwisata, industri, dan sumber daya alam. Kabupaten Gianyar merupakan kabupaten yang terkenal sebagai kota seni dan budaya dengan potensi pariwisata yang baik. Terdapat banyak objek pariwisata yang menjadi andalan pemerintah Kabupaten Gianyar dalam menarik minat wisatawan untuk berkunjung, ini merupakan potensi sumber daya yang dapat dimanfaatkan oleh pemerintah Kabupaten Gianyar menjadi sumber pendapatan asli daerah yang bisa sangat membantu pembangunan di Kabupaten Gianyar. 
Kebijakan pemerintah daerah Kabupaten Gianyar dalam memanfaatkan segala potensi yang dimiliki Kabupaten Gianyar akan sangat berpengaruh pada pendapatan asli daerah bila dapat dikelola dengan baik. Dengan demikian pemerintah daerah Kabupaten Gianyar tidak lagi bergantung dari sumbangan dana pemerintah pusat dalam membiayai pembangunan di daerah. Pertumbuhan pendapatan daerah mengalami kenaikan atau penurunan tergantung dari seberapa besar sumber-sumber keuangan daerah mampu menghasilkan pendapatan bagi daerahnya. Mohammed et al. (2015) menyatakan bahwa Pendapatan daerah merupakan komponen yang sangat penting pada suatu daerah karena digunakan untuk membiayai segala program-program yang direncanakan oleh pemerintah daerah yang bertujuan untuk meningkatkan kesejahteraan masyarakat dan perekonomian daerah.

Pertumbuhan pendapatan daerah dipengaruhi oleh seberapa besar sumber-sumber keuangan daerah mampu menghasilkan pendapatan bagi daerahnya. Belanja modal menunjukan rencana jangka panjang dan pembelanjaan atas aktiva tetap seperti gedung, peralatan, kendaraan, perabotan, dan sebagainya (Mardiasmo, 2018:83). Potensi-potensi yang dimiliki daerah diharapkan agar mampu dimanfaatkan dengan baik agar sumber keuangan yang bersumber dari pendapatan asli daerah dapat meningkat (Taras dan Artini, 2017). Salah satu kegiatan belanja daerah juga turut berperan dalam menghasilkan sumber pendapatan daerah yang bersumber dari potensi-potensi yang dimiliki daerah.

Penelitian yang dilakukan oleh Aydin et al. (2016) yang memperoleh hasil jika belanja pemerintah berada di atas ambang batas, maka berpengaruh positif terhadap pertumbuhan ekonomi. Argumen tersebut juga senada dengan hasil penelitian yang dilakukan Amuka et al. (2016) yang menyatakan bahwa belanja pemerintah dapat menyebabkan terjadinya stabilitas pada perekonomian. Belanja modal merupakan belanja pemerintah yang mampu memberikan kontribusi terhadap pertumbuhan pendapatan daerah. Mohammed et al. (2015) berpendapat bahwa belanja modal adalah salah satu kegiatan belanja pemerintah daerah yang dapat meningkatkan aktiva tetap dan dapat memberikan manfaat dalam jangka waktu panjang.

Ukuran keberhasilan dari setiap kegiatan belanja modal adalah mutu yang diberikan sesuai dengan yang diharapkan, sesuatu yang dihasilkan sesuai dengan jumlah yang dibutuhkan, pelaksanaan kegiatan belanja modal sesuai dengan waktu yang telah ditentukan, mengarah pada kepentingan publik, dan biaya yang dikeluarkan untuk kegiatan belanja modal semestinya tidak melebihi anggaran yang sudah ditetapkan sebelumnya (Halim, 2008:228-229). Berkembang pesatnya pembangunan infrastruktur di suatu daerah, mampu mendorong kegiatan investasi di daerah tersebut, sehingga berdampak terhadap pertumbuhan pendapatan daerah pada masa yang akan datang, perekonomian daerah yang semakin berkembang dan dapat menciptakan lapangan pekerjaan bagi masyarakat setempat.

Pengelolaan keuangan daerah yang tercermin pada Anggaran Pendapatan dan Belanja Daerah masing-masing daerah dapat digunakan sebagai instrumen untuk membuat peraturan dalam pembangunan daerah sehingga laporan pertanggungjawaban keuangan daerah wajib untuk diberikan setiap 
tahunnya (Lucky, 2013). Kinerja keuangan pemerintah dapat diukur dari seberapa besar kemampuan pemerintah daerah dalam menggali potensi-potensi yang dimiliki daerahnya sehingga mampu memberikan kontribusi terhadap pertumbuhan pendapatan daerah setiap tahunnya. Kinerja keuangan pemerintah daerah pada penelitian ini diukur dengan menggunakan rasio pertumbuhan pendapatan daerah.

Pertumbuhan pendapatan daerah mengalami kenaikan setiap tahunnya menyebabkan pemerintah daerah mampu memenuhi segala kebutuhan daerahnya dan memberikan indikasi bahwa keuangan daerah telah mampu dikelola dengan baik oleh pemerintah daerah. Pemerintah berperan dalam mengelola keuangan daerah sangat penting untuk meningkatkan kemampuannya dalam menghasilkan sumber-sumber keuangan agar dapat meminimalkan terjadinya penurunan pertumbuhan pendapatan daerah setiap tahunnya. Beberapa penelitian sebelumnya juga meneliti mengenai pengaruh pendapatan asli daerah terhadap kinerja keuangan pemerintah daerah. Penelitian Antari dan Sedana (2018) pendapatan asli daerah berpengaruh positif signifikan terhadap kinerja keuangan pemerintah daerah Kabupaten/Kota Provinsi Bali tahun 2011-2015. Hasil ini mengindikasikan bahwa pendapatan asli daerah yang dihasilkan Kabupaten/Kota Provinsi Bali Tahun 2011- 2015 mampu memberikan kontribusi terhadap pertumbuhan pendapatan daerah Kabupaten/Kota Provinsi Bali tahun 2011-2015. Penelitian Nugroho dan Rohman (2012) memberikan hasil bahwa tingginya penerimaan pendapatan asli daerah dapat meningkatkan kemandirian pemerintah daerah sehingga hal tersebut berimplikasi pada kinerja keuangan pemerintah daerah. Darwanis dan Saputra (2014) mengemukakan bahwa pemerintah dapat meningkatkan pendapatan asli daerah melalui pungutan yang bersumber dari pajak daerah dan retribusi daerah sehingga pemerintah daerah dapat meningkatkan pertumbuhan kinerja keuangannya. Julitawati et al (2012), dan Wenny (2012) juga menemukan bahwa pendapatan asli daerah berpengaruh positif signifikan terhadap kinerja keuangan pemerintah daerah. Pada sisi lain penelitian yang dilakukan Mulyani dan Wibowo (2017) mendapatkan hasil bahwa pendapatan asli daerah berpengaruh negatif signifikan terhadap kinerja keuangan pemerintah daerah yang memberikan indikasi bahwa peningkatan pendapatan asli daerah dapat menurunkan kinerja keuangan pemerintah daerah.

Belanja modal juga digunakan sebagai variabel bebas pada penelitian ini karena kegiatan belanja modal juga berpengaruh terhadap pertumbuhan pendapatan daerah yang merupakan proyeksi dari kinerja keuangan pemerintah daerah. Hasil penelitian Astiti dan Mimba (2016) menunjukkan bahwa pengalokasian dana pada belanja modal yang lebih banyak nantinya dapat membantu daerah untuk memperoleh sumber keuangan sehingga mengasilkan pendapatan daerah. Hal tersebut berimplikasi pada peningkatan kinerja keuangan pemerintah daerah. Mulyani dan Wibowo (2017) juga menemukan bahwa belanja modal berpengaruh positif signifikan terhadap kinerja keuangan pemerintah daerah. Sedangkan penelitian yang dilakukan Nugroho dan Rohman (2012) mendapatkan hasil bahwa belanja modal berpengaruh negatif signifikan terhadap pertumbuhan kinerja keuangan daerah secara langsung. Hasil ini memberikan indikasi bahwa kinerja dari pegawai kurang maksimal dan 
anggaran belanja modal sering digunakan untuk kepentingan pribadi sehingga menimbulkan tindakan korupsi. Penelitian yang dilakukan oleh Darwanis dan Saputra (2014) juga mendapatkan hasil bahwa belanja modal berpengaruh negatif terhadap kinerja keuangan pemerintah daerah.

Penelitian yang di lakukan oleh Antari dan Sedana (2018) juga mendapat hasil bahwa belanja modal berpengaruh negatif signifikan terhadap kinerja keuangan pemerintah daerah Kabupaten/Kota Provinsi Bali tahun 2011-2015. Hasil ini memberikan arti bahwa kegiatan belanja modal yang dilakukan pemerintah daerah Kabupaten/Kota Provinsi Bali tahun 2011-2015 belum sepenuhnya mampu memberikan kontribusi terhadap pertumbuhan pendapatan daerah Kabupaten/Kota Provinsi Bali tahun 2011-2015.

Kinerja (performance) menurut kamus akuntansi manajemen dikatakan sebagai aktivitas terukur dari suatu entitas selama periode tertentu sebagai bagian dari ukuran keberhasilan pekerjaan. Pengukuran kinerja diartikan sebagai suatu sistem keuangan atau non keuangan dari suatu pekerjaan yang dilaksanakan atau hasil yang dicapai dari suatu aktivitas, suatu proses atau suatu unit organisasi. Pengukuran kinerja sangat penting untuuk menilai akuntabilitas organisasi dan manajer dalam menghasilkan pelayanan publik yang lebih baik. Tujuan dilakukan pengukuran kinerja yang pertama untuk membantu memperbaiki kinerja pemerintah, ukuran kinerja yang dimaksud untuk dapat membantu pemerintah berfokus pada tujuan dan sasaran program unit kerja. Kedua untuk mengalokasikan sumber daya dan pembuatan keputusan. Ketiga untuk mewujudkan pertanggungjawaban publik dan memperbaiki komunikasi kelembagaan (Mardiasmo, 2018:151).

Kinerja keuangan pemerintah daerah adalah tingkat pencapaian dari suatu hasil kerja di bidang keuangan daerah yang meliputi peneriman dan belanja daerah dengan menggunakan sistem keuangan yang ditentukan melalui suatu kebijakan atau ketentuan perundang-undangan selama satu periode anggaran. Bentuk dari pengukuran kinerja tersebut berupa rasio keuangan yang terbentuk dari sistem laporan pertanggungjawaban daerah berupa perhitungan APBD. Pemerintah daerah sebagai pihak yang diserahi tugas menjalankan roda pemerintahan, pembangunan, dan pelayanan masyarakat wajib menyampaikan laporan pertanggungjawaban keuangan daerahnya untuk dinilai apakah pemerintah daerah berhasil menjalankan tugasnya dengan baik atau tidak. Salah satu alat untuk menganalisis kinerja pemerintah daerah dalam mengelola keuangan daerahnya adalah dengan melakukan analisis rasio keuangan terhadap APBD yang telah ditetapkan dan dilaksanakannya.

Pendapatan Asli Daerah (PAD) berdasarkan Undang-Undang Nomor 33 Tahun 2004 tentang perimbangan keuangan antara Pusat dan Daerah pasal 1 angka 18 bahwa, pendapatan asli daerah adalah pendapatan yang diperoleh daerah yang dipungut berdasarkan peraturan daerah sesuai dengan peraturan perundang-undangan. Pendapatan Asli Daerah adalah penerimaan yang diperoleh dari sumber-sumber pendapatan di dalam daerahnya sendiri. Pendapatan Asli Daerah tersebut dipungut berdasarkan peraturan daerah yang sesuai dengan peraturan perundang-undangan yang berlaku di Indonesia. Pendapatan Asli Daerah (PAD) adalah segenap pemasukan atau penerimaan yang masuk ke dalam kas daerah, diperoleh dari sumber-sumber dalam 
wilayahnya sendiri, dipungut berdasarkan Peraturan Daerah sesuai peraturan perundang-undangan yang berlaku dan dipergunakan untuk keperluam daerah. Oleh karena itu, tiap-tiap daerah harus mengupayakan agar dapat dipungut seintensif mungkin. Pendapatan Asli Daerah adalah penerimaan yang diperoleh dari sektor pajak daerah, retribusi daerah, hasil perusahaan milik daerah, hasil pengelolaan kekayaan daerah yang dipisahkan, dan lain-lain pendapatan asli daerah yang sah.

Belanja Modal adalah pengeluaran yang manfaatnya cenderung melebihi satu tahun anggaran dan akan menambah aset atau kekayaan pemerintah, dan selanjutnya akan menambah anggaran rutin untuk biaya operasional dan pemeliharaan. Belanja modal menunjukan rencana jangka panjang dan pembelanjaan atas aktiva tetap seperti gedung, peralatan, kendaraan, perabotan, dan sebagainya. Belanja modal yang besar biasanya dilakukan dengan menggunakan pinjaman. Pada dasarnya, pemerintah tidak mempunyai uang yang dimiliki sendiri, sebab seluruhnya adalah milik publik. Dalam sebuah masyarakat demokratis, rakyat memberi mandat kepada pemerintah melalui proses pemilihan umum.

Politisi menjalankan mandat tersebut dalam bentuk kebijakan publik dan program yang memberi manfaat bagi pemilih yang direfleksikan dalam anggaran. Adanya keterbatasan sumber daya, menyembabkan anggaran mempunyai trade-off, sebagian uang tidak dapat dialokasikan untuk suatu bidang tanpa mengurangi jumlah alokasi pada bidang yang lain, atau adanya penambahan jumlah pajak yang dibayar publik. Pemerintah memutuskan bidang mana yang akan didahulukan atau diprioritaskan. Anggaran berfungsi sebagai alat politis yang diguunakan untuk memutuskan prioritas dan kebutuhan keuangan pada sektor tersebut (Mardiasmo, 2018:83).

Pendapatan Asli Derah adalah penerimaan yang diperoleh dari sumbersumber pendapatan di dalam daerahnya sendiri. Menurut Abdul dan Muhammad (2012) pemerintah daerah sebagai pihak yang diserahi tugas menjalankan roda pemerintahan, pembangunan, dan pelayanan masyarakat wajib menyampaikan laporan pertanggungjawaban keuangan daerahnya untuk dinilai apakah pemerintah daerah berhasil menjalankan tugasnya dengan baik atau tidak. Dalam organisasi pemerintahan daerah kinerja dalam mendistribusikan pendapatan atau sumber daya publik sebaiknya didistribusikan secara merata dan adil antar daerah dan antara masyarakat miskin dengan yang kaya dapat dikurangi. Tujuan pemerintah daerah mengadakan distribusi untuk mengusahakan pemerataan distribusi pendapatan dan pemerataan pembangunan daerah.

Teori distribusi adalah ilmu yang mempelajari tentang penyaluran atau pembagian kepada beberapa orang atau beberapa tempat agar dapat tersalurnya tujuan secara merata. Anggaran sebagai alat distribusi yaitu untuk mendistribusikan pendapatan atau sumber daya publik agar menjadi pemerataan dan keadilan ekonomi atar daerah dan antara masyarakat miskin dengan yang kaya dapat dikurangi. Mekanisme distribusi ekonomi melalui anggaran sektor publik dilakukan dalam bentuk pemberian subsidi kepada masyarakat, pemberian dana transfer atau perimbangan, dan melalui programprogram masyarakat. Pemberian subsidi dimaksudkan untuk mengurangi 
kesenjangan ekonomi antar daerah, pemerintah memberikan dana perimbangan sebagai bentuk subsidi silang dari daerah kaya ke daerah yang miskin sumber daya ekonominya (Mahmudi, 2006). Fungsi distribusi adalah untuk mengusahakan pemerataan distribusi pendapatan dan pemerataan pembangunan.

Hasil dari beberapa penelitian sebelumnya juga meneliti mengenai pengaruh pendapatan asli daerah terhadap kinerja keuangan pemerintah daerah. Penelitian Nugroho dan Rohman (2012) memberikan hasil bahwa tingginya penerimaan pendapatan asli daerah dapat meningkatkan kemandirian pemerintah daerah sehingga hal tersebut berimplikasi pada kinerja keuangan pemerintah daerah. Darwanis dan Saputra (2014) mengemukakan bahwa pemerintah dapat meningkatkan pendapatan asli daerah melalui pungutan yang bersumber dari pajak daerah dan retribusi daerah sehingga pemerintah daerah dapat meningkatkan pertumbuhan kinerja keuangannya. Julitawati et al (2012), dan Wenny (2012) juga menemukan bahwa pendapatan asli daerah berpengaruh positif signifikan terhadap kinerja keuangan pemerintah daerah. Pada sisi lain penelitian yang dilakukan Mulyani dan Wibowo (2017) mendapatkan hasil bahwa pendapatan asli daerah berpengaruh negatif signifikan terhadap kinerja keuangan pemerintah daerah yang memberikan indikasi bahwa peningkatan pendapatan asli daerah dapat menurunkan kinerja keuangan pemerintah daerah.

Hasil Penelitian Antari dan Sedana (2018) bahwa pendapatan asli daerah berpengaruh positif signifikan terhadap kinerja keuangan pemerintah daerah Kabupaten/Kota Provinsi Bali tahun 2011-2015. Hasil ini mengindikasikan bahwa pendapatan asli daerah yang dihasilkan Kabupaten/Kota Provinsi Bali Tahun 2011- 2015 mampu memberikan kontribusi terhadap pertumbuhan pendapatan daerah Kabupaten/Kota Provinsi Bali tahun 2011-2015. Berdasarkan hal tersebut, hipotesis penelitian yang diujikan adalah sebagai berikut.

$\mathrm{H}_{1}$ : Pendapatan Asli Daerah Berpengaruh Positif pada Kinerja Keuangan Pemerintah Daerah Kabupaten Gianyar.

Belanja Modal adalah pengeluaran yang manfaatnya cenderung melebihi satu tahun anggaran dan akan menambah aset atau kekayaan pemerintah, dan selanjutnya akan menambah anggaran rutin untuk biaya operasional dan pemeliharaan. Belanja modal menunjukan rencana jangka panjang dan pembelanjaan atas aktiva tetap seperti gedung, peralatan, kendaraan, perabotan, dan sebagainya. Pengelolaan keuangan yang baik dapat dilihat dari kebijakan pemerintah daerah yang lebih banyak mengalokasikan anggaran pada kepentingan masyarakat yang disebut belanja modal. Dalam kinerja keuangan pemerintahan daerah sebaiknya pendapatan daerah dapat didistribusikan dengan merata untuk belanja modal dan belanja-belanja lainnya agar pembangunan daerah dan keperluan dari pemerintahan sendiri dapat terpenuhi dengan baik. Hasil penelitian Astiti dan Mimba (2016) menunjukkan bahwa pengalokasian dana pada belanja modal yang lebih banyak nantinya dapat membantu daerah untuk memperoleh sumber keuangan sehingga mengasilkan pendapatan daerah, sehingga hal tersebut berimplikasi pada peningkatan kinerja keuangan pemerintah daerah. Mulyani dan Wibowo (2017) juga menemukan bahwa belanja modal berpengaruh positif signifikan terhadap kinerja keuangan pemerintah daerah. 
Penelitian yang dilakukan Nugroho dan Rohman (2012) mendapatkan hasil bahwa belanja modal berpengaruh negatif signifikan terhadap pertumbuhan kinerja keuangan daerah secara langsung. Hasil ini memberikan indikasi bahwa kinerja dari pegawai kurang maksimal dan anggaran belanja modal sering digunakan untuk kepentingan pribadi sehingga menimbulkan tindakan korupsi. Penelitian yang dilakukan oleh Darwanis dan Saputra (2014) juga mendapatkan hasil bahwa belanja modal berpengaruh negatif terhadap kinerja keuangan pemerintah daerah. Penelitian yang di lakukan oleh Antari dan Sedana (2018) juga mendapat hasil bahwa belanja modal berpengaruh negatif signifikan terhadap kinerja keuangan pemerintah daerah Kabupaten/Kota Provinsi Bali tahun 2011-2015. Berdasarkan hal tersebut, hipotesis penelitian ini adalah sebagai berikut.

$\mathrm{H}_{2}$ : Belanja Modal berpengaruh negatif pada Kinerja Keuangan Pemerintah Daerah Kabupaten Gianyar.

\section{METODE PENELITIAN}

Lokasi dari penelitian ini pada Badan Pengelolaan Keuangan dan Aset Daerah (BPKAD). Sementara ruang lingkup dari penelitian ini adalah 38 Organisasi Perangkat Daerah (OPD) Kabupaten Gianyar.

Populasi yang digunakan dalam penelitian ini adalah Organisasi Perangkat Darah (OPD) yang berjumlah 38 OPD. Sampel yang digunakan dalam penelitian ini adalah seluruh anggota populasi yakni Laporan Realisasi APBD Kabupaten Gianyar tahun 2015-2017, yang temasuk dalam sampel sebanyak 36 OPD pada kurun waktu 3 tahun.

Teknik analisis yang digunakan pada penelitian ini yaitu dengan menggunakan Analisis Regresi Linear Berganda dengan menggunakan program SPSS (Statistical Product and Service Solution). Teknik analisis regresi berganda digunakan dalam penelitian ini karena variabel bebas lebih dari satu dan merupakan teknik uji yang digunakan untuk mengetahui pengaruh variabel independen terhadap variabel dependen, dengan persamaan sebagai berikut:

$Y=a 0+\beta_{1} X_{1}+\beta_{2} X_{2}+\varepsilon$

Keterangan:

$Y:$ Kinerja Keuangan Pemerintah Daerah
$\alpha 0:$ Konstanta
$X_{1}:$ Pendapatan Asli Daerah
$X_{2}:$ Belanja Modal
$\beta 1, \beta 2:$ koefisien regresi variabel bebas
$\varepsilon:$ Standar eror (Error Term)

\section{HASIL DAN PEMBAHASAN}

Analisis deskriptif adalah langkah pertama yang perlu dilakukan untuk mengetahui bagaimana gambaran umum data yang telah dikumpulkan terkait variabel penelitian. Analisis statistik deskriptif disajikan untuk memberikan informasi umum tentang karakteristik variabel penelitian yang berupa nilai tertinggi, nilai terendah, rata-rata, dan deviasi standar dari variabel pendapatan asli daerah, belanja modal dan kinerja keuangan. Hasil statistik deskriptif dapat dilihat pada Tabel 2 berikut. 
Tabel 2. Hasil Uji Statitik Deskriptif

\begin{tabular}{lcrrrr}
\hline & $\mathrm{N}$ & \multicolumn{1}{c}{ Minimum } & \multicolumn{1}{c}{ Maximum } & \multicolumn{1}{c}{ Mean } & \multicolumn{1}{c}{ Std. Deviation } \\
\hline PAD & 108 & 5910000.00 & 1119612769640.0 & 414351985253.61 & 260477610433.1561 \\
Belanja & 108 & 5500000.00 & 314688079529.0 & 9185819006.12 & 40213533783.91043 \\
$\begin{array}{l}\text { Modal } \\
\text { Kinerja }\end{array}$ & 108 & & & & \\
$\begin{array}{l}\text { Keuangan } \\
\text { Valid N }\end{array}$ & 108 & .02 & 111.80 & 46.6478 & 25.85453 \\
(listwise) & & & & & \\
\hline
\end{tabular}

Sumber: Data Penelitian, 2019

Data pada Tabel 2 menunjukkan pendapatan asli daerah terendah adalah sebesar Rp 5.910.000 sedangkan pendapatan asli daerah tertinggi adalah sebesar Rp. 1.119.612.769.640 yaitu pada Sekretariat Daerah tahun 2016. Nilai rata-rata PAD di Kabupaten Gianyar adalah sebesar Rp. 414.351.985.253,61 dengan nilai standar deviasi sebesar Rp. 260.477.610.433,15. Hal ini berarti nilai standar deviasi pada variabel PAD lebih besar dibandingkan dengan nilai rata-ratanya, yang berarti sebaran data terkait dengan PAD di Pemerintah Daerah Kabupaten Gianyar tidak merata.

Belanja modal terendah adalah sebesar Rp 5.500.000 terdapat pada Dinas Peternakan, Periklanan dan Kelautan, sedangkan belanja modal tertinggi adalah sebesar Rp. 314.688.079.528,80 yaitu pada Dinas Pendapatan. Nilai rata-rata PAD di Kabupaten Gianyar adalah sebesar Rp. 9.185.819.006,12 dengan nilai standar deviasi sebesar Rp. 40.213.533.783,90. Hal ini berarti nilai standar deviasi pada variabel belanja modal lebih besar dibandingkan dengan nilai rata-ratanya, yang berarti sebaran data terkait dengan belanja modal di Pemerintah Daerah Kabupaten Gianyar tidak merata.

Kinerja keuangan terendah adalah sebesar 0,02 persen terdapat pada Dinas Pendidikan, Pemuda dan Olahraga tahun 2015, sedangkan kinerja keuangan tertinggi adalah sebesar 111,8 yaitu pada RSUD Sanjiwani Gianyar tahun 2015. Nilai rata-rata kinerja keuangan pemerintah daerah Kabupaten Gianyar adalah sebesar 46,65 persen dengan nilai standar deviasi sebesar 25,85 persen. Hal ini berarti nilai standar deviasi pada variabel kinerja keuangan lebih besar dibandingkan dengan nilai rata-ratanya, yang berarti sebaran data terkait dengan kinerja keuangan di Pemerintah Daerah Kabupaten Gianyar tidak merata.

Uji normalitas ini bertujuan untuk mengetahui apakah residual dari model regresi yang dibuat berdistribusi normal atau tidak. Dalam penelitian ini uji normalitas dilakukan dengan menguji normalitas residual dengan menggunakan uji Kolmogrov Smirnov. Jika probabilitas signifikansi nilai residual lebih besar dari 0,05 maka data tersebut dikatakan berdistribusi normal. Demikian pula sebaliknya, jika probabilitas signifikansi residual lebih rendah dari 0,05 maka data tersebut dikatakan tidak berdistribusi normal. Uji Normalitas Data disajikan pada Tabel 3 berikut. 
Tabel 3. Hasil Uji Normalitas

\begin{tabular}{cc}
\hline & Unstandardized Residual \\
\hline $\mathrm{N}$ & 108 \\
Kolmogrov Smirnov Z & 0,760 \\
Asymp.Sig.(2-tailed) & 0,610 \\
\hline
\end{tabular}

Sumber: Data Penelitian, 2019

Berdasarkan hasil uji normalitas pada Tabel 3 didapat nilai signifikansi sebesar 0,610. Oleh karena nilai signifikansi uji Kolmogorov-Smirnov lebih dari 0,05 maka dapat disimpulkan bahwa model persamaan regresi tersebut berdistribusi normal.

Uji multikolinearitas bertujuan untuk menguji apakah dalam satu model regresi ditemukan adanya korelasi antar variabel bebas. Model regresi yang baik adalah tidak terjadi korelasi diantara variabel bebas. Untuk mendeteksi ada atau tidaknya korelasi antar variabel bebas dapat dilihat dari nilai tolerance dan nilai variance inflation factor (VIF). Jika nilai tolerance lebih dari $10 \%$ atau VIF Kurang dari 10, maka dapat dikatakan model telah bebas dari multikolinearitas. Uji Multikolinieritas disajikan pada Tabel 4 berikut.

Tabel 4. Hasil Uji Multikoleniaritas

\begin{tabular}{lccc}
\hline \multicolumn{1}{c}{ Variabel } & Tolerance & VIF & Keterangan \\
\hline Pendapatan Asli Daerah $\left(\mathrm{X}_{1}\right)$ & 0,992 & 1,008 & Bebas multikol \\
Belanja Modal $\left(\mathrm{X}_{2}\right)$ & 0,992 & 1,008 & Bebas multikol \\
\hline
\end{tabular}

Sumber: Data Penelitian, 2019

Berdasarkan Tabel 4 dapat dilihat bahwa nilai tolerance dan VIF dari seluruh variable tersebut menunjukkan bahwa nilai tolerance untuk setiap variabel lebih besar dari 10\% dan nilai VIF lebih kecil dari 10 yang berarti model persamaan regresi bebas dari multikolinearitas.

. Uji autokorelasi dilakukan untuk melacak adanya korelasi data dari tahun $\mathrm{t}$ dengan tahun $\mathrm{t}-1$ (sebelumnya). Pengujian autokorelasi dilakukan melalui Durbin-Watson test, dimana model regresi dikatakan terbebas dari autokorelasi apabila sesuai dengan kriteria du<DW $<4-d u$. Hasil uji autokorelasi dapat dilihat pada Tabel 5 sebagai berikut.

Tabel 5. Hasil Uji Autokorelasi

\begin{tabular}{cccccc}
\hline No & Dl & Du & $4-d u$ & DW & Simpulan \\
\hline 1 & 1,6488 & 1,7241 & 2,2759 & 2,251 & Bebas autokorelasi \\
\hline
\end{tabular}

Sumber: Data Penelitian, 2019

Tabel 5 menunjukkan bahwa besarnya nilai Durbin Watson sebesar 2,251. Nilai $\mathrm{D}-\mathrm{W}$ menurut tabel dengan $\mathrm{n}=108$ dan $\mathrm{k}=2$ didapat nilai $\mathrm{dl}=1,6488 \mathrm{dan}$ nilai $d u=1,7241$. Oleh karena nilai $d u<d w<(4-d u)$ yaitu $(1,7241<2,251<2,2759)$, maka dapat disimpulkan tidak terdapat autokorelasi antar residual.

Uji heteroskedastisitas ini bertujuan untuk mengetahui apakah dalam model regresi terjadi ketidaksamaan varians dari residual satu pengamatan ke pengamatan lain yang dilakukan dengan uji Glejser. Model regresi yang baik adalah yang tidak mengandung gejala heteroskedastisitas atau mempunyai varians yang homogen. Jika variabel bebas yang diteliti tidak mempunyai pengaruh signifikan atau nilai signifikansinya lebih dari 0,05 terhadap nilai absolute residual, berarti model regresi tidak mengandung gejala 
heteroskedastisitas. Hasil pengujian heteroskedastisitas disajikan pada Tabel 6 berikut.

Tabel 6. Hasil Uji Heteroskedastisitas

\begin{tabular}{cccc}
\hline No & Variabel Bebas & Signifikansi & Keterangan \\
\hline 1 & Pendapatan Asli Daerah & 0,336 & Bebas heteroskedastisitas \\
2 & Belanja Modal & 0,633 & Bebas heteroskedastisitas \\
\hline
\end{tabular}

Sumber: Data Penelitian, 2019

Pada Tabel 6 dapat dilihat bahwa nilai signifikansi dari variabel Pendapatan Asli Daerah sebesar 0,336, dan Belanja Modal sebesar 0,633. Nilai tersebut lebih besar dari 0,05 yang berarti tidak terdapat pengaruh antara variabel bebas terhadap absolute residual. Dengan demikian, model yang dibuat tidak mengandung gejala heteroskedastisitas.

Setelah semua asumsi klasik terpenuhi, maka selanjutnya memaparkan hasil analisis regresi linier berganda. Perhitungan koefisien regresi linier berganda dilakukan dengan analisis regresi melalui software SPSS 18.0 for Windows, diperoleh hasil yang ditunjukan pada Tabel 7 berikut.

Tabel 7. Hasil Analisis Regresi Linier Berganda

\begin{tabular}{|c|c|c|c|c|c|c|}
\hline \multirow{2}{*}{\multicolumn{2}{|c|}{ Model }} & \multicolumn{2}{|c|}{$\begin{array}{l}\text { Unstandardized } \\
\text { Coefficients }\end{array}$} & \multirow[t]{2}{*}{$\begin{array}{l}\text { Standardized } \\
\text { Coefficients }\end{array}$} & \multirow[b]{2}{*}{$l$} & \multirow[b]{2}{*}{ Sig. } \\
\hline & & B & Std. Error & & & \\
\hline \multirow[t]{3}{*}{1} & (Constant) & -.081 & .046 & & -1.772 & .079 \\
\hline & PAD & .454 & .087 & .447 & 5.195 & .000 \\
\hline & Belanja Modal & -.303 & .118 & -.220 & -2.565 & .012 \\
\hline
\end{tabular}

Sumber: Data Penelitian, 2019

Berdasarkan hasil analisis regresi linier berganda seperti yang disajikan pada Tabel 7, maka dapat dibuat persamaan regresi sebagai berikut:

$$
\mathrm{Y}=-0,081+0,454 \mathrm{X}_{1}-0,303 \mathrm{X}_{2}
$$

Hasil menunjukkan seluruh variabel memiliki nilai signifikansi kurang dari 0,05 . Hal ini berarti bahwa terdapat pengaruh yang signifikan dari variabel bebas tehadap variabel terikatnya.

Uji ketepatan model regresi bertujuan untuk mengetahui apakah semua variabel bebas yang diidentifikasi (Pendapatan Asli Daerah, dan Belanja Modal) tepat digunakan memprediksi kinerja keuangan pemerintah daerah. Uji ini sering juga disebut dengan uji F. Hasil uji F dapat dilihat pada Tabel 8 berikut.

Tabel 8. Hasil Uji F

\begin{tabular}{llrrrrr}
\hline Model & & Sum of Squares & df & Mean Square & F & \multicolumn{1}{c}{ Sig. } \\
\hline 1 & Regression & 6.306 & 2 & 3.153 & 15.721 & $.000^{\mathrm{a}}$ \\
& Residual & 21.060 & 105 & .201 & & \\
& Total & 27.366 & 107 & & & \\
\end{tabular}

Sumber: Data Penelitian, 2019

Hasil uji $\mathrm{F}$ ( $F$ test) pada Tabel 8 menunjukkan bahwa nilai $\mathrm{F}$ hitung sebesar 15,721 dengan nilai signifikansi $P$ value 0,000 yang lebih kecil dari $\alpha=0,05$, ini berarti model yang digunakan pada penelitian ini adalah layak. Hasil ini memberikan makna bahwa kedua variabel independen yaitu Pendapatan Asli Daerah, dan Belanja Modal tepat memprediksi atau menjelaskan fenomena kinerja keuangan pemerintah daerah. Dengan kata lain, Pendapatan Asli Daerah dan Belanja Modal secara simultan berpengaruh signifikan pada kinerja keuangan pemerintah daerah di Kabupaten Gianyar. 
Untuk mengetahui dan mengukur kemampuan model dalam menerangkan variasi variabel independen digunakan koefisien determinasi $\left(R^{2}\right)$. Peneliti menggunakan nilai adjusted $\mathrm{R}^{2}$ pada saat mengevaluasi yang mana model regresi terbaik, karena nilai adjusted $\mathrm{R}^{2}$ dapat naik atau turun apabila satu variabel independen ditambahkan ke dalam model. Hasil uji koefisien determinasi dapat dilihat pada Tabel 9 berikut.

Tabel 9. Hasil Uji Koefisien Determinasi

\begin{tabular}{ccccc}
\hline Model & $R$ & $R$ Square & Adjusted $R$ Square & $\begin{array}{c}\text { Std. Error of the } \\
\text { Estimate }\end{array}$ \\
\hline 1 & $0,480^{\mathrm{a}}$ & 0,230 & 0,216 & 0,44784687 \\
\hline
\end{tabular}

Sumber: Data Penelitian, 2019

Hasil uji memberikan hasil dimana diperoleh besarnya adjusted $\mathrm{R}^{2}$ (koefisien determinasi yang telah disesuaikan) adalah 0,216 . Ini berarti variasi Kinerja keuangan pemerintah daerah dapat dipengaruhi secara signifikan oleh variabel Pendapatan Asli Daerah, dan Belanja Modal sebesar 21,6 persen sedangkan sisanya sebesar 78,4 persen dijelaskan oleh faktor-faktor lain yang tidak dijelaskan dalam model penelitian

Pengaruh variabel Pendapatan Asli Daerah, dan Belanja Modal terhadap kinerja keuangan pemerintah daerah diuji dengan menggunakan Uji t. Kriteria pengujian untuk menjelaskan interpretasi pengaruh antar masing-masing variabel yakni apabila nilai signifikansi $<0,05$ maka $\mathrm{H}_{0}$ ditolak dan $\mathrm{H}_{1}$ diterima. Sebaliknya, jika nilai signifikansi $>0,05$ maka $\mathrm{H}_{0}$ diterima dan $\mathrm{H}_{1}$ ditolak.

Berdasarkan hasil analisis pengaruh Pendapatan Asli Daerah terhadap Kinerja keuangan pemerintah daerah diperoleh nilai signifikansi sebesar 0,000 dengan nilai koefisien regresi positif sebesar 0,454. Nilai signifikansi 0,000<0,05 mengindikasikan bahwa $\mathrm{H}_{1}$ diterima. Hasil ini mempunyai arti bahwa Pendapatan Asli Daerah berpengaruh positif dan signifikan terhadap kinerja keuangan pemerintah daerah di Kabupaten Gianyar.

Berdasarkan hasil analisis pengaruh Belanja Modal terhadap kinerja keuangan pemerintah daerah diperoleh nilai signifikansi sebesar 0,012 dengan nilai koefisien regresi negatif sebesar -0,303. Nilai signifikansi 0,012<0,05 mengindikasikan $\mathrm{H}_{2}$ diterima. Hasil ini mempunyai arti bahwa Belanja Modal berpengaruh negatif dan signifikan terhadap kinerja keuangan pemerintah daerah di Kabupaten Gianyar.

Hipotesis pertama $\left(\mathrm{H}_{1}\right)$ menyatakan bahwa Pendapatan Asli Daerah berpengaruh positif dan signifikan terhadap kinerja keuangan. Hasil analisis pada Tabel 7 menunjukan bahwa nilai koefisien positif sebesar 0,454 dengan tingkat signifikansi 0,000 lebih kecil dari taraf nyata dalam penelitian yaitu $a=$ 0,05. Hal ini menunjukan bahwa Pendapatan Asli Daerah berpengaruh positif dan signifikan terhadap kinerja keuangan pemerintah daerah di Kabupaten Gianyar, berarti semakin tinggi Pendapatan Asli Daerah, maka semakin tinggi kinerja keuangan pemerintah. Pendapatan Asli Daerah adalah penerimaan yang diperoleh dari sumber-sumber pendapatan di dalam daerahnya sendiri. Tingginya penerimaan pendapatan asli daerah dapat meningkatkan kemandirian pemerintah daerah sehingga hal tersebut berimplikasi pada kinerja keuangan pemerintah daerah. Dalam organisasi pemerintahan daerah kinerja dalam mendistribusikan pendapatan atau sumber daya publik sebaiknya 
didistribusikan secara merata dan adil antar OPD hal ini mendukung teori distribusi. Tujuan pemerintah daerah mengadakan distribusi untuk mengusahakan pemerataan distribusi pendapatan dan pemerataan pembangunan daerah. Hasil penelitian ini sejalan dengan penelitian yang dilakukan oleh Nugroho dan Rohman (2012), Darwanis dan Saputra (2014), Julitawati et al (2012), Wenny (2012), serta Antari dan Sedana (2018) menunjukan bahwa Pendapatan Asli Daerah berpengaruh positif pada Kinerja Keuangan.

Hipotesis kedua $\left(\mathrm{H}_{2}\right)$ menyatakan bahwa Belanja Modal berpengaruh negatif pada kinerja keuangan. Hasil analisis pada Tabel 4.6 menunjukkan bahwa nilai koefisien regresi negatif sebesar -0,303 dengan tingkat signifikansi 0,000 lebih kecil dari taraf nyata dalam penelitian yaitu $a=0,05$. Hal ini menunjukan bahwa Belanja Modal berpengaruh negatif dan signifikan terhadap kinerja keuangan Pemerintah Daerah.

Belanja modal menunjukan rencana jangka panjang dan pembelanjaan atas aktiva tetap seperti gedung, peralatan, kendaraan, perabotan, dan sebagainya. Pengelolaan keuangan yang baik dapat dilihat dari kebijakan pemerintah daerah yang lebih banyak mengalokasikan anggaran pada kepentingan masyarakat yang disebut belanja modal. Hasil penelitian ini mendukung teori distribusi yakni dalam kinerja keuangan pemerintahan daerah sebaiknya pendapatan daerah dapat didistribusikan dengan merata untuk belanja modal dan belanja-belanja lainnya agar pembangunan daerah dan keperluan dari pemerintahan sendiri dapat terpenuhi dengan baik.

Hasil penelitian ini sejalan dengan penelitian yang dilakukan oleh Nugroho dan Rohman (2012), Darwanis dan Saputra (2014), serta Antari dan Sedana (2018) menunjukan bahwa Belanja Modal berpengaruh negatif pada Kinerja Keuangan.

Hasil penelitian ini secara teoritis dapat memberikan bukti empiris mengenai pengaruh pendapatan asli daerah dan belanja modal pada kinerja keuangan serta dapat mengkonfirmasi teori distribusi khususnya pada pendapatan asli daerah yakni dalam mendistribusikan pendapatan secara merata ke OPD. Semakin Tingginya penerimaan pendapatan asli daerah dapat meningkatkan kemandirian pemerintah daerah sehingga hal tersebut berimplikasi pada kinerja keuangan pemerintah daerah.

Hasil penelitian ini secara praktis dapat digunakan sebagai masukan dan bahan pertimbangan kepada pemerintah daerah untuk menentukan kebijakan dalam meningkatkan ataupun memperbaiki kinerja keuangan pemerintah daerah sekaligus sebagai referensi untuk menentukan strategi yang tepat guna menggali pendapatan daerah dengan sumber daya yang dimiliki agar dapat meningkatkan belanja daerah demi meningkatkan kinerja keuangan pemerintah.

\section{SIMPULAN}

Pendapatan asli daerah berpengaruh positif dan signifikan pada kinerja keuangan pemerintahan daerah Kabupaten Gianyar. Berarti meningkatnya pendapatan asli daerah, maka kinerja keuangan pemerintah daerah juga meningkat. Belanja modal berpengaruh negatif dan signifikan pada kinerja keuangan pemerintah daerah Kabupaten Gianyar. Hal ini berarti semakin tinggi 
belanja modal, maka semakin rendah tingkat kinerja keuangan pemerintah daerah.

Pemerintah daerah diharapkan melakukan upaya-upaya untuk meningkatkan kinerja keuangan pemerintah melalui alokasi belanja seperti yang diatur dalam UU Nomor 15 tahun 2013, tentang anggaran pendapatan dan belanja negara diantaranya pengalokasian dana untuk pendidikan, bidang kesehatan, dan seluruh peraturan terkait alokasi pendapatan dan belanja daerah. Pemerintah Daerah diharapkan dapat mengalokasikan Belanja Modal dengan sebijak mungkin serta dapat didistribusikan secara merata ke OPD dan melaporkan pengeluaran yang dilakukan pemerintah secara transparan dalam rangka peningkatan kesejahteraan masyarakat.

\section{REFERENSI}

Abdul, H., \& Muhammad, S. K. (2012). Teori, Konsep dan Aplikasi Akuntansi Sektor Publik. Jakarta: Salemba Empat.

Amuka, J. I., Ezeoke, M. O., \& Asogwa, F. O. (2016). Government Spending Pattern and Macroeconomic Stability: A Vector Autoregressive Model. International Journal of Economics and Financial Issues, 6(4), 1930-1936.

Antari, N. P. G. S., \& Sedana, I. B. P. (2018). Pengaruh Pendapatan Asli Daerah Dan Belanja Modal Terhadap Kinerja Keuangan Pemerintah Daerah. EJurnal Manajemen Unud, 7(2), 1080-1110.

Astiti, D. N. Y., \& Mimba, N. P. S. H. (2016). Pengaruh Belanja Rutin Dan Belanja Modal Pada Kinerja Keuangan Pemerintah Daerah. E-Jurnal Akuntansi Universitas Udayana, 14(3), 1924-1950.

Aydin, C., Akinci, M., \& Yilmaz, O. (2016). The Analysis of Visible Hand of Government: The Threshold Effect of Government Spending on Economic Growth. International Journal of Trade, Economics and Finance, 7(5), 170-178. https:// doi.org/10.18178/ijtef.2016.7.5.518

Badan Pusat Statistik. 2016. Statistik Keuangan Pemerintah Kabupaten/Kota SeProvinsi Bali Tahun 2013-2017. Provinsi Bali Dalam Angka 2017. Denpasar: BPS Bali

Darwanis, \& Saputra, R. (2014). Pengaruh Belanja Modal Terhadap Pendapatan Asli Daerah Dan Dampaknya Pada Kinerja Keuangan Pemerintah Daerah (Studi Empiris Pada Pemerintah Daerah Kabupaten/Kota Di Provinsi Aceh). Jurnal Dinamika Akuntansi Dan Bisnis, 1(2), 183-199.

Halim, A. (2008). Akuntansi Keuangan Daerah. Jakarta: Salemba Empat.

Julitawati, E., Darwanis, \& Jalaluddin. (2012). Pengaruh Pendapatan Asli Daerah (PAD) dan Kinerja Keungan Pemerintah Kabupaten/Kota di Provinsi Bali. Jurnal Akuntansi, 1(1), 15-29.

Lucky, D. (2013). Analysis Of The Effect Of Regional Financial Performance To Economic Growth and Poverty Through Capital Expenditure (Case study of 38 Regencies/Cities in East Java Province ). Journal of Economics and Sustainable Development, 4(19), 7-18.

Mahmudi. (2006). Akuntansi Sektor Publik. Yogyakarta: UII Press.

Mardiasmo. (2018). Akuntansi Sektor Publik. Yogyakarta: ANDI.

Mohammed, A., Ahmed, B. B., \& Salihu, A. M. (2015). Expenditure And Internally Generated Revenue Relationship: An Analysis Of Local 
Governments In Adamawa State, Nigeria. Journal of Arts, Science $\mathcal{E}$ Commerce, 6(3), 67-77.

Mulyani, S., \& Wibowo, H. (2017). Pengaruh Belanja Modal, Ukuran Pemerintah Daerah, Intergovernmental Revenue dan Pendapatan Asli Daerah terhadap Kinerja Keuangan. Kompartemen, 15(1), 57-66.

Nugroho, F., \& Rohman, A. (2012). Pengaruh Belanja Modal terhadap Pertumbuhan Kinerja Keuangan Daerah dengan Pendapatan Asli Daerah sebagai Variabel Intervening. Diponegoro Journal of Accounting, 1(2), 1-14.

Pemerintah Indonesia. Undang-Undang Republik Indonesia Nomor 33 Tahun 2004 tentang Perimbangan Keuangan (2004). Jakarta.

Pemerintah Indonesia. Undang-Undang Republik Indonesia Nomor 23 Tahun 2014 tentang Pemerintah Daerah (2014). Jakarta.

Pemerintah Kabupaten Gianyar. 2018. Situs Resmi Pemerintahan Kabupaten Gianyar. https://www.gianyarkab.go.id. Diakses 28 September 2018.

Rondonuwu, R. H., Tinangon, J. J., \& Budiarso, N. (2015). Analisis Efisiensi Dan Efektivitas Pengelolaan Keuangan Daerah Pada Dinas Pendapatan Daerah Kabupaten Minahasa. Jurnal EMBA, 3(4), 23-32.

Rosemary, O., Justine, C., \& Barry, B. (2016). Local Government Financial Autonomy: A Comparative Analysis Of Nigeria And Brazil. Arabian Journal of Business and Management Review (OMAN Chapter), 5(10), 38-54.

Sujarweni, W. (2015). Akuntansi Sektor Publik. Yogyakarta: Penerbit Pustaka Baru Press.

Taras, T., \& Artini, L. G. S. (2017). Analisis Pendapatan Asli Daerah (PAD) Dalam Upaya Pelaksanaan Otonomi Daerah Di Kabupaten Badung Bali. E-Jurnal Manajemen Unud, 6(5), 2360-2387.

Wenny, C. D. (2012). Analisis Pengaruh Pendapatan Asli Daerah (PAD) Terhadap Kinerja Keuangan Pada Pemerintah Kabupaten dan Kota Di Propinsi Sumatera Selatan. Jurnal Ilmiah STIE MDP, 2(1), 39-51. 